\title{
Sifat Fisik dan Organoleptik Bubur Daging Buah Merah (Pandanus conoideus Lamk)
} Physical and Organoleptic Properties of Red Fruit (Pandanus conoideus Lamk) Puree

\author{
Dela Vikantika Ponglabba, Zita Letviany Sarungallo dan Budi Santoso*
}

Jurusan Teknologi Pertanian, Fakultas Teknologi Pertanian, Universitas Papua,

Jl. Gunung Salju Amban Manokwari 98314, Papua Barat

\section{Riwayat Naskah:}

Diterima 062020 Direvisi 062020 Disetujui 062020
ABSTRAK: Bubur daging buah merah (Pandanus conoideus Lamk) diperoleh tanpa didahului proses ekstraksi minyak dan ditambahkan pengemulsi, penstabil dan bahan lainnya seperti garam, gula dan asam sitrat. Bubur daging buah merah merupakan bahan baku yang dapat digunakan untuk pembuatan selai, dodol dan kue. Penelitian ini bertujuan untuk menentukan sifat fisik dan organoleptik beberapa formula bubur daging buah merah. Bubur daging buah merah dibuat dengan perlakuan jenis pengemulsi dan penstabil yaitu F0 (kontrol), F1 (Tween 80 2\% dan CMC 1\%), F2 (gelatin 2\%), dan F3 (Tween 80 0,5\% dan gelatin 1\%). Sifat fisik dari keempat formulasi bubur daging buah merah adalah berwarna merah hingga merah oranye, beraroma khas buah merah, $\mathrm{pH}$ 6,64, viskositas 108-150 dPa.s, total padatan terlarut 8,4 - 8,5 ${ }^{\circ}$ Brix, dengan kestabilan emulsi 2 sampai 7 hari. Berdasarkan hasil pengujian organoleptik, formula bubur daging buah merah yang paling disukai panelis adalah F3 dengan komposisi daging buah merah 95,1\%, Tween 80 0,5\%, gelatin $1 \%$, garam $0,3 \%$, gula $3 \%$ dan asam sitrat $0,1 \%$, dengan tingkat penerimaan warna dengan skor 5,8 (agak suka sampai suka), aroma 4,9 (netral sampai agak suka), rasa 5,0 (agak suka), dan tampilan produk secara keseluruhan 5,0 (agak suka).

Kata kunci: buah merah (Pandanus conoideus Lamk), bubur daging buah , sifat fisik, sifat organoleptik

ABSTRACT: Red fruit (Pandanus conoideus Lamk) puree is fruit pulp obtained without the process of extracting oil and added with emulsifier and stabilizer agents as well other supporting materials such as salt, sugar and citric acid. This study aims to determine the physical and organoleptic properties of some red fruit puree formulas. Red fruit puree was made in four formulations using type of emulsifier and stabilizer, F0 (control), F1 (Tween $802 \%$ and CMC 1\%), F2 (Gelatin 2\%), and F3 (Tween $800.5 \%$ and 1\% Gelatin). The physical properties of four formulations of red fruit puree were red to red-orange, the distinctive aroma of red fruit, pH 6.64, viscosity 108-150 dPa.s, total dissolved solids 8,4 8,5 Brix, with emulsion stability of 2 to 7 days. Based on organoleptic testing, the red fruit puree formula that was most preferred by panelists was F3 $(95,1 \%$ fruit flesh, Tween 80 $0,5 \%$; $1 \%$ gelatin; $0,3 \%$ salt; $3 \%$ sugar and $0,1 \%$ citric acid) with a color attribute tend to be liked with the score was 5,8; while the aroma, taste, and the overall appearance of the product tend to slightly liked with the score were 4,$9 ; 5,0 ; 5,0$, respectively.

Keywords: red fruit (Pandanus conoideus Lamk), puree, physical properties, organoleptic properties

\footnotetext{
* Kontributor utama

Email: budsandida@yahoo.com
} 


\section{Pendahuluan}

Buah merah (Pandanus conoideus Lamk) merupakan salah satu famili Pandanaceae yang penyebarannya ditemui hampir di seluruh dataran Papua. Secara fisik buahnya terdiri dari kumpulan bulir (drupa) yang melekat pada empulur (pedicel), dimana setiap bulir terdiri dari daging buah (pulp) yang melekat pada biji (Sarungallo et al., 2019). Daging buah merah dilaporkan mengandung protein 1,86 - 2,66\%, lemak 50,8 - 55,58\%, karbohidrat $36,78-46,3 \%$, abu 2,7 - 5,03\%, dengan kadar total karotenoid sebesar 552 - 1592 ppm dan total tokoferol berkisar 544 - 2016 ppm (Sarungallo et al., 2016). Dengan kandungan komponen aktif yaitu karotenoid dan tokoferol yang cukup tinggi menyebabkan buah merah merupakan sumber antioksidan alami dan berpotensi untuk diolah sebagai pangan fungsional.

Pemanfaatan buah merah secara tradisional oleh masyarakat seperti yang tinggal di sekitar Pegunungan Arfak dan Wamena adalah sebagai sumber minyak, pasta untuk cocolan sagu, ubi jalar atau dikonsumsi secara langsung (Roreng dan Nishigaki, 2013). Pengembangan produk berbasis buah merah telah dilaporkan, seperti ekstrak minyak buah merah sebagai suplemen (Nishigaki dan Waspodo, 2007), dan aneka produk pangan lainnya seperti dodol (Murtiningrum dan Silamba, 2010), selai dan saos (Murtiningrum et al., 2012).

Pemanfaatan daging buah merah yang secara langsung dipisahkan dari bijinya dalam bentuk bubur daging buah (puree) merah belum pernah dilaporkan. Menurut SNI 7841:2013 (BSN, 2013), puree buah atau bubur daging buah adalah produk buah yang diperoleh dari buah segar atau buah yang dibekukan dengan kematangan yang cukup yang dihancurkan tanpa mengekstrak sari buahnya dengan atau tanpa bahan tambahan yang diizinkan. Bubur daging buah merah merupakan produk antara yang dapat diolah lebih lanjut sebagai bahan baku pembuatan saos, selai, dodol, dan berbagai kue seperti bolu.

Komponen utama dalam bubur daging buah merah adalah daging buah, air dan minyak sehingga relatif tidak stabil. Permasalahan dalam pembuatan bubur daging buah merah adalah ketidakstabilannya selama penyimpanan karena adanya fraksi minyak dan air. Salah satu cara untuk mengatasi masalah tersebut adalah dengan menggunakan bahan pengemulsi dan penstabil (Murtiningrum et al., 2013).

Beberapa jenis pengemulsi dan penstabil yang dapat digunakan adalah carboxyl methyl cellulose (CMC), polyoxyethylene sorbitan monooleate (tween 80), dan gelatin (Murtiningrum et al., 2013). Namun hingga saat ini belum diketahui jenis emulsifier yang sesuai agar bubur daging buah merah dapat stabil selama penyimpanan, serta bagaimana sifat fisik dan organoleptiknya. Oleh karena itu penelitian ini bertujuan untuk memformulasi bubur daging buah merah menggunakan CMC, Tween 80 dan gelatin sebagai pengemulsi dan penstabil dan menentukan sifat fisik dan organoleptik beberapa formula bubur daging buah merah yang dihasilkan.

\section{Bahan dan Metode}

\subsection{Bahan}

Bahan baku utama dalam penelitian ini adalah buah merah yang berasal dari Distrik Manyambo, Kabupaten Pegunungan Arfak, Provinsi Papua Barat, Indonesia. Sedangkan bahan tambahan dalam pembuatan bubur daging buah merah adalah polyoxyethylene sorbitan monooleate (tween 80), carboxyl methyl cellulose (CMC), gelatin, gula, garam dan asam sitrat.

\subsection{Alat}

Peralatan yang digunakan dalam penelitian ini adalah pengaduk, panci, saringan, homogenizer (WiseMix HG-15A, Daihan Sci, Korea,), dan timbangan analitik (WAS 220/C/2 Radwag, Polandia). Sedangkan alat untuk analisis yaitu viscometer (Viscotester VT-04F, Japan), hand refractometer (Atago N-IE, Japan), dan $\mathrm{pH}$ meter (pH/Ion 510, Eutech Instruments, USA).

\subsection{Metode penelitian}

\subsubsection{Pembuatan dan formulasi bubur daging buah merah}

Daging buah merah dihasilkan dengan cara pipilan buah merah direbus dalam air selama \pm 15 menit dengan perbandingan bulir dan air $(1: 0,5)$. Setelah itu dilakukan pemisahan daging buah dengan biji dengan penambahan air dan dilakukan penyaringan. Filtrat yang diperoleh kemudian dipanaskan selama \pm 10 menit, setelah itu filtrat didinginkan 30 menit serta dilakukan penyaringan dan pengendapan sebanyak 5 kali. Sehingga bagian yang tertinggal di atas saringan disebut dengan daging buah. Daging buah yang diperoleh kemudian diformulasikan dengan bahan-bahan pendukung lainnya untuk membuat bubur daging buah merah. Perlakuan formulasi bubur daging buah merah disajikan pada Tabel 1.

Proses pembuatan bubur daging buah merah dilakukan dengan cara mencampurkan semua bahan-bahan sesuai formulasi pada Tabel 1. Bahanbahan tersebut kemudian dimasak selama \pm 5 menit, setelah itu dilakukan proses homogenisasi \pm 3 menit menggunakan homogenizer dan langsung 
Citation: Ponglabba, D. V, Sarungallo, Z. L dan Santoso, B. (2020). Sifat Fisik dan Organoleptik Bubur Daging Buah Merah (Pandanus conoideus Lamk) Warta IHP, 37(1),58-65

Halaman | 60

Tabel 1.

Perlakuan konsentrasi pengemulsi dan penstabil bubur daging buah merah

\begin{tabular}{lcccc}
\hline & Bahan & \multicolumn{3}{c}{ Formulasi (\%) } \\
\cline { 2 - 5 } & F0 & F1 & F2 & F3 \\
\hline Daging buah merah & 96,6 & 93,6 & 94,6 & 95,1 \\
Tween 80 & - & 2 & - & 0,5 \\
CMC & - & 1 & - & - \\
Gelatin & - & - & 2 & 1 \\
Garam & 0,3 & 0,3 & 0,3 & 0,3 \\
Gula & 3 & 3 & 3 & 0,1 \\
Asam sitrat & 0,1 & 0,1 & 0,1 & 0,1 \\
\hline
\end{tabular}

dimasukkan ke dalam botol $30 \mathrm{~mL}$ yang sudah disterilkan.

\subsubsection{Analisis sifat fisik}

Karakteristik fisik bubur daging buah merah dilakukan dengan mengukur viskositas menggunakan viscometer, total padatan terlarut menggunakan alat refraktometer, $\mathrm{pH}$ menggunakan pH meter. Deteksi aroma dilakukan menggunakan indera penciuman sedangkan untuk warna dan kestabilan emulsi diamati secara visual.

\subsubsection{Pengujian organoleptik}

Pengujian organoleptik dari keempat formula bubur daging buah merah dilakukan dengan menggunakan dua cara uji, yaitu uji hedonik dan uji penjenjangan. Uji hedonik dilakukan untuk mengetahui tingkat penerimaan panelis terhadap formula bubur daging buah merah berdasarkan tingkat kesukaan terhadap warna, aroma, rasa dan tampilan produk secara keseluruhan dengan skor (1) sangat tidak suka, (2) tidak suka, (3) agak tidak suka, (4) netral, (5) agak suka, (6) suka dan (7) sangat suka (Setyaningsih et al., 2010). Panelis yang digunakan adalah panelis terlatih sebanyak 25 orang yang terdiri dari mahasiswa pada Jurusan Teknologi Pertanian, Universitas Papua.

\subsubsection{Analisis data}

Data hasil pengujian sifat fisik (viskositas dan total padatan terlarut) dan hasil pengujian organoleptik bubur daging buah merah dianalisis secara statistik menggunakan analisis sidik ragam (Analisis of Varians) pada tingkat kepercayaan 95\% dan jika perlakuan berpengaruh nyata, maka dilanjutkan dengan Uji Jarak Berganda Duncan. Sedangkan untuk sifat fisik (warna, aroma, kestabilan emulsi dan $\mathrm{pH}$ ) disajikan dalam Tabel 2 dan dibahas secara deskriptif.

\section{Hasil dan Pembahasan}

\subsection{Sifat fisik bubur daging buah merah}

Karakteristik sifat fisik bubur daging buah merah meliputi warna, aroma, pH dan stabilitas emulsinya disajikan pada Tabel 2. Warna pada bubur daging buah merah berasal dari bahan baku yang digunakan yaitu daging buah merah yang secara alami berwarna merah disebabkan oleh kandungan karotenoidnya, yang semakin meningkat dengan meningkatnya tingkat kematangan buah (Sarungallo et al., 2016). Sarungallo et al. (2016) melaporkan pula bahwa kandungan karotenoid buah merah yang sudah matang berkisar 552 - 1073 ppm. Formula (F1 dan F3) menghasilkan warna merah orange (Tabel 1). Hal ini menunjukkan bahwa formula yang ditambahkan 2\% Tween 80 maka pengemulsian menjadi lebih sempurna sehingga akan diikuti dengan perubahan warna dari warna merah menjadi merah oranye (Gambar 1). Murtiningrum et al. (2013) juga melaporkan bahwa emulsi minyak buah merah yang stabil akan ditandai dengan terjadinya perubahan warna dari yang awalnya berwarna merah berubah menjadi warna merah oranye.

Untuk mengetahui aroma dari bahan pangan, dilakukan uji deteksi aroma menggunakan indera penciuman (Setyaningsih et al., 2010). Data pada Tabel 2 menunjukkan bahwa keempat formula bubur daging buah merah memiliki aroma yang khas buah merah, dengan demikian penambahan bahanbahan lainnya seperti garam, gula, asam sitrat, pengemulsi dan penstabil tidak menghilangkan aroma spesifik buah merah.

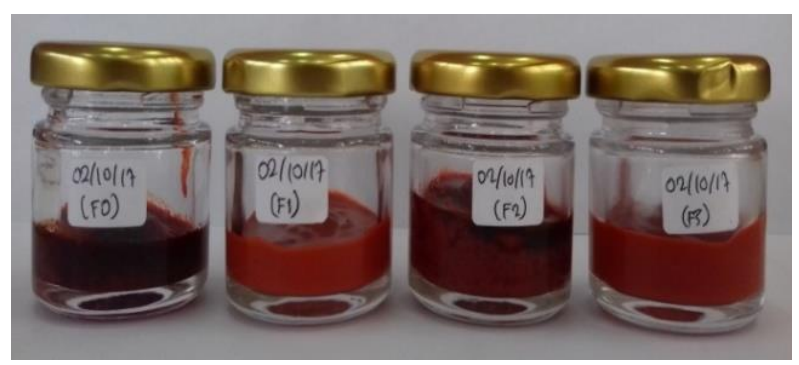

Gambar 1. Keempat formula bubur daging buah merah 
Tabel 2.

Karakteristik sifat fisik formula bubur daging buah merah

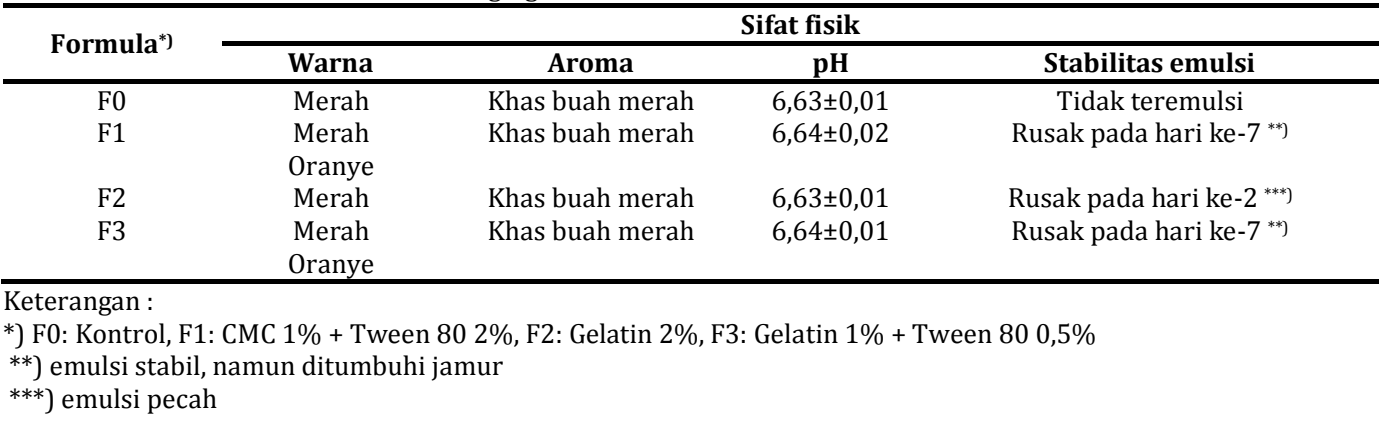

Bubur daging buah merah dari keempat formula mempunyai tingkat keasaman $(\mathrm{pH})$ berkisar 6,63 6,64. Hal ini menunjukkan bahwa dengan penambahan garam, gula, asam sitrat, CMC, tween 80 dan gelatin tidak memberikan kontribusi terhadap nilai $\mathrm{pH}$ dari keempat formula bubur daging buah merah yang dihasilkan. Tingkat keasaman $(\mathrm{pH})$ dengan nilai $(>5,0)$ tergolong dalam bahan pangan tidak asam sehingga sangat rentan untuk ditumbuhi oleh bakteri anaerobik (Effendi, 2015). Menurut Buckle et al. (2013), mikroorganisme pembusuk sangat berpotensi untuk tumbuh pada kisaran pH 6,0 - 8,0. Oleh karena itu untuk mencegah kerusakan tersebut maka dalam tahap pengolahannya perlu dilakukan proses pasteurisasi setelah tahap pembotolan sehingga dapat memperpanjang umur simpan bubur daging buah merah. Menurut Effendi (2015), pasteurisasi merupakan proses pemanasan makanan di bawah suhu didih dengan tujuan untuk membunuh bakteri patogen.

Stabilitas emulsi merupakan suatu keadaan dimana terdapat keseragaman ukuran partikel fase pendispersi dan fase terdispersi dengan konfigurasi yang baik (Suryani et al., 2002). Emulsi didefinisikan sebagai suatu sistem yang heterogen yang mengandung dua fase cairan dimana satu cairan terdispersi sebagai globular-globular dalam medium pendispersi dalam bentuk butiran. Faktor yang paling penting untuk mutu suatu produk emulsi adalah stabilitas emulsinya (Suryani et al., 2002). Data pada Tabel 2 menunjukkan bahwa bubur daging buah merah tanpa adanya pengemulsi dan penstabil (F0) tidak dapat membentuk emulsi. Hal ini disebabkan karena kedua fraksi minyak dan air masih memiliki tegangan permukaan yang berbeda dan tidak saling melarutkan sehingga kedua fraksi tersebut tetap terpisah walaupun sudah dilakukan homogenisasi. Dengan penggunaan pengemulsi dan penstabil dapat menghasilkan emulsi bubur daging buah merah dengan kestabilan 2-7 hari yaitu pada formula (F1, F2 dan F3). Murtiningrum et al. (2013) melaporkan juga bahwa pengemulsi dan penstabil yang mampu membentuk emulsi minyak buah merah yaitu tween 20 , tween 80 dan CMC.

Formula F2 (gelatin 2\%) pada Tabel 2 menunjukkan bahwa walaupun dapat membentuk emulsi, tetapi stabilitas emulsi yang diperoleh relatif singkat yaitu 2 hari, yang menunjukkan adanya kerusakan yaitu pecahnya emulsi bubur daging buah merah. Hal ini menunjukkan bahwa gelatin tidak dapat menstabilkan emulsi bubur daging buah merah dalam waktu yang cukup lama, karena memiliki kemampuan yang terbatas untuk mengikat dan mempertahankan struktur gel. Menurut Schreiber dan Gareis (2007), gelatin dapat membentuk emulsi karena komponen utama gelatin yang merupakan kompleks polipeptida dengan kemampuan sebagai pengemulsi dan penstabil. Gelatin memiliki fungsi sebagai agen pembentuk gel yang dapat mengubah cairan menjadi padatan yang elastis, lentur dan lunak (Hasniati, 2012). Sedangkan dengan penggunaan pengemulsi dan penstabil (F1 dan F3) dalam formulasi dapat menambah kestabilan emulsi bubur daging buah merah lebih lama, namun pada hari ke-7 telah ditumbuhi mikroorganisme (jamur). Adanya serangan jamur pada bubur daging buah merah dapat disebabkan karena belum melalui tahapan pasteurisasi setelah proses pembotolan.

Penggunaan pengemulsi (Tween 80) dan penstabil (CMC) secara bersamaan dapat memperpanjang kestabilan emulsi. CMC dapat membentuk emulsi yang disebabkan karena memiliki kapasitas mengikat air dari gugus fungsi karboksimetil $\left(\mathrm{CH}_{2} \mathrm{CO}=0\right)$, selain itu juga karena aktivitas permukaan yang nyata dari CMC pada permukaan minyak dan air (Hayati et al., 2011). Dijelaskan pula bahwa adanya kemampuan CMC meningkatkan gaya tolak antar droplet minyak dapat mencegah penyatuan kembali droplet minyak dan berdampak pada stabilitas sistem emulsi (Hayati et al., 2011). Sementara itu, penggunaan gelatin sebagai agen pembentuk gel dapat mengubah cairan menjadi padatan yang elastis, lentur dan lunak (Hasniati, 2012), sedangkan Tween 80 memiliki gugus hidroksil, oksietilen dan 


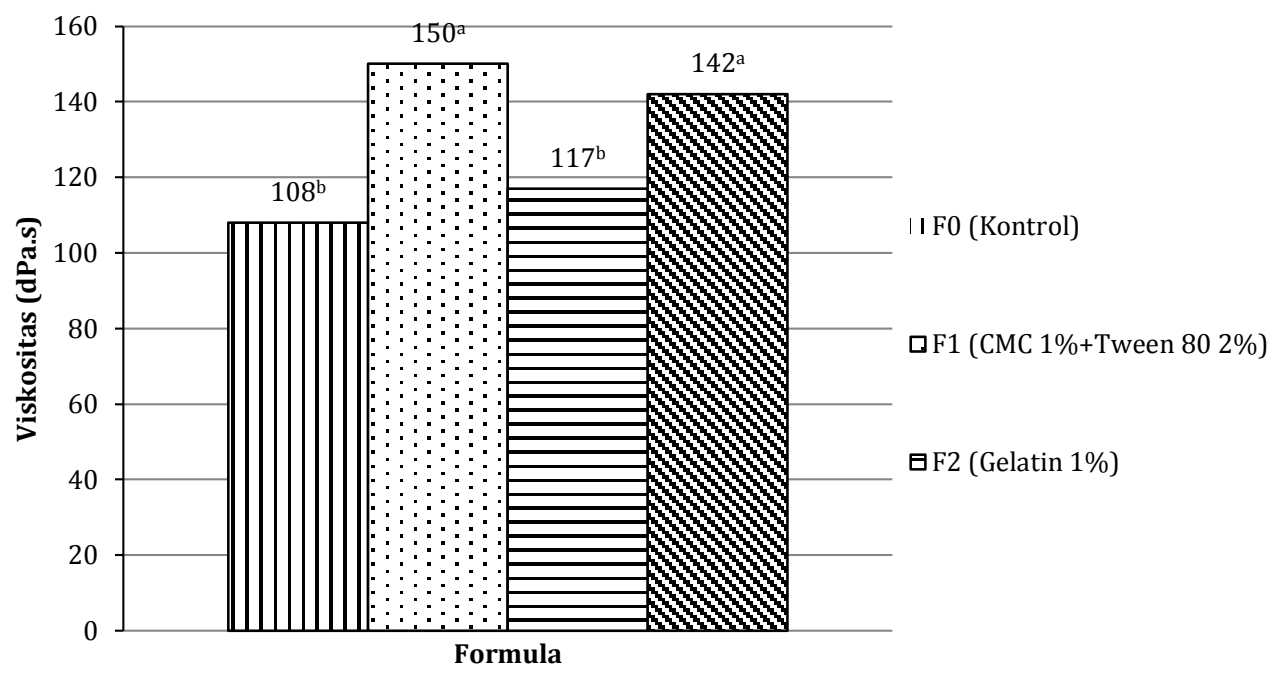

* Gambar 2. Viskositas keempat formula bubur daging buah merah. Huruf yang sama di belakang angka menunjukkan tidak berbeda nyata

hidrokarbon rantai panjang sehingga dapat mempertahankan stabilitas emulsi air dalam minyak (Hsu dan Nacu, 2003). Hal ini juga diperkuat Joshi et al. (2012) yang mengatakan bahwa pelarut fase terdispersi dalam fase pendispersi lebih mudah terjadi dengan bertambahnya panjang rantai hidrokarbon. Murtiningrum et al (2013) melaporkan bahwa Tween 80 dapat membentuk emulsi minyak buah merah karena pengemulsi bersifat hidrofilik tetapi larut dalam lemak. Sifat hidrofilik Tween 80 dikarenakan keberadaan gugus hidroksil dan oksietilen.

Viskositas merupakan tingkat kekentalan produk. Semakin tinggi nilai viskositas suatu produk maka produk tersebut semakin kental (Kumalasari et al., 2015). Data pada Gambar 2 memperlihaktan bahwa perlakuan formulasi bubur daging buah merah berpengaruh nyata $(\mathrm{P}<0,05)$ terhadap viskositasnya. Hasil uji lanjut Duncan pada tingkat kepercayaan 95\% menunjukkan bahwa viskositas terendah adalah formula tanpa penggunaan pengemulsi dan penstabil (F0) yaitu 108 dPa.s tidak berbeda nyata dengan penggunaan penstabil (F2), namun berbeda nyata dengan formula (F1 dan F3) dengan perlakuan pengemulsi dan penstabil. Viskositas tertinggi diperoleh dari formula (F1) yang menggunakan pengemulsi dan penstabil yaitu CMC dan Tween 80 sebesar 150 dPa.s. Hal ini disebabkan karena adanya CMC sebagai stabiliser dan Tween 80 sebagai emulsifier.

Mekanisme peningkatan viskositas pada F1 yang menggunakan pengemulsi dan penstabil dikarenakan fungsi dari CMC adalah dapat meningkatkan viskositas bubur daging buah merah yang disebabkan oleh molekul-molekul air yang terperangkap dalam struktur gel (Sarungallo et al.,
2014). Selain itu CMC juga berfungsi sebagai pengental dan penstabil (Cahyadi, 2012). Murtiningrum et al. (2013) juga melaporkan bahwa semakin tinggi konsentrasi CMC yang digunakan, emulsi minyak buah merah yang diperoleh semakin kental. Sedangkan Tween 80 sebagai pengemulsi tidak memberikan peningkatan viskositas pada bubur daging buah merah dikarenakan fungsi dari tween 80 adalah untuk menurunkan tegangan antar muka udara-cairan dan cairan-cairan untuk mempermudah terbentuknya emulsi dan untuk menyatukan dua jenis bahan yang tidak saling melarutkan (Suryani et al., 2002). Murtiningrum et al. (2013) juga melaporkan bahwa peningkatan konsentrasi Tween 80 tidak berpengaruh terhadap viskositas emulsi minyak buah merah yang dihasilkan. Djelaskan pula bahwa peningkatan konsentrasi Tween 80 sampai 1\% pada rasio minyak dan air yang sama dapat menghasilkan emulsi dengan kekentalan yang relatif sama dengan penggunaan konsentrasi pengemulsi Tween 80 0,375\% (Murtiningrum et al., 2013). Total padatan terlarut menunjukkan kandungan bahan-bahan yang terlarut dalam larutan. Komponen yang terkandung dalam buah terdiri atas komponen-komponen yang larut air, seperti glukosa, fruktosa dan sukrosa (Farikha et al., 2013). Pengukuran total padatan terlarut dimaksudkan untuk mengetahui kandungan total gula dari keempat formula bubur daging buah merah. Hasil analisis total padatan terlarut keempat formula bubur daging buah merah berkisar antara 8,53 - 8,47 ${ }^{\circ}$ Brix (Gambar 3) masih memenuhi SNI 7841:2013 (BSN, 2013) puree buah yaitu 7,0 - 20,0 ${ }^{0}$ Brix. 


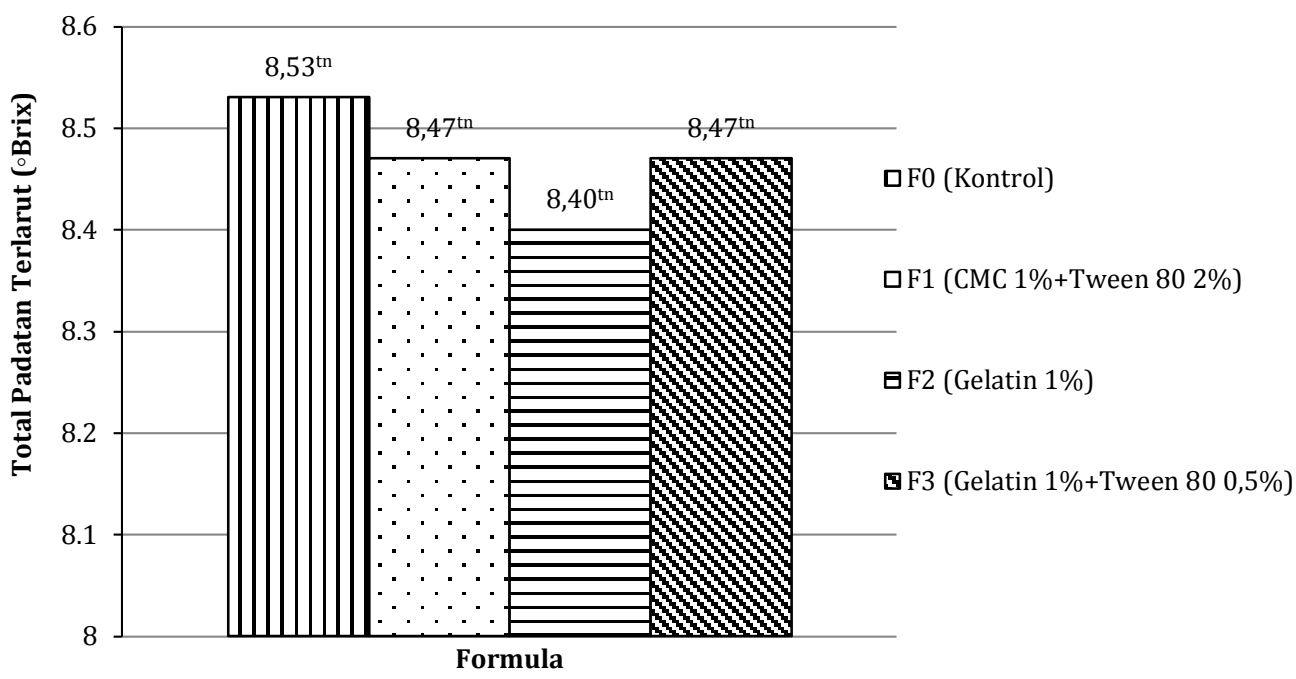

Gambar 3. Total padatan terlarut keempat formula bubur daging buah merah. (Huruf yang sama di belakang angka menunjukkan tidak berbeda nyata)

\subsection{Sifat organoleptik bubur daging buah merah}

Hasil pengujian organoleptik berdasarkan tingkat kesukaan panelis (uji hedonik) terhadap warna, aroma, rasa dan penilaian keseluruhan dari keempat formula bubur daging buah merah disajikan pada Tabel 3.

Warna merupakan salah satu parameter sensori yang diamati dengan menggunakan indera penglihatan (Setyaningsih et al., 2010). Data pada Tabel 3 menunjukkan bahwa tingkat kesukaan panelis terhadap warna bubur daging buah merah dari keempat formula berkisar agak suka sampai suka dengan skor 5,1 - 5,8. Hal ini disebabkan karena warna keempat formula bubur daging buah merah tersebut relatif sama yaitu merah sampai merah oranye. Warna merah hingga merah oranye yang terdapat pada bubur daging buah merah ini berasal dari warna alami daging buah yang mengandung pigmen karotenoid yang merupakan kelompok pigmen yang berwarna kuning, merah dan oranye pada lemak hewan dan tumbuhan (Nishigaki dan Waspodo, 2007).
Aroma merupakan salah satu sifat sensori yang dapat dikenali dengan bau produk atau senyawa tertentu yang sudah umum dikenal melalui indera penciuman (Setyaningsih et al., 2010). Hasil yang diperoleh pada Tabel 3 menunjukkan bahwa aroma dari keempat formula bubur daging buah merah berkisar netral sampai agak suka dengan skor 4,3 4,9. Hal ini disebabkan karena keempat formula bubur daging buah merah memiliki aroma yang sama yaitu beraroma khas buah merah dan tidak menyimpang dari aroma pandan.

Rasa merupakan salah satu parameter uji organoleptik untuk menentukan tingkat kesukaaan panelis dengan menggunakan indera pencicip (Setyaningsih et al., 2010). Hasil pada Tabel 3 menunjukkan bahwa rasa bubur daging buah merah dari keempat formula berkisar agak tidak suka cenderung netral sampai agak suka dengan skor 3,8 - 5,0. Hal ini menunjukkan bahwa perlakuan tanpa penggunaan penggemulsi dan penstabil (kontrol), serta perlakuan dengan penggunaan pengemulsi dan penstabil dari keempat formula bubur daging buah merah walaupun konsentrasi gula, garam dan asam sitrat keempat formulanya sama.

Tabel 3.

Hasil pengujian tingkat kesukaan (hedonik) panelis terhadap bubur daging buah merah

\begin{tabular}{|c|c|c|c|c|}
\hline \multirow{2}{*}{ Formula*) } & \multicolumn{4}{|c|}{ Parameter bubur daging buah merah } \\
\hline & Warna* $^{* *}$ & Aroma*) $^{* *}$ & Rasa**) & Keseluruhan**) \\
\hline F0 & $5,1 \pm 1,28^{\text {tn }}$ & $4,3 \pm 0,96^{\text {tn }}$ & $4,3 \pm 1,59^{\mathrm{ab}}$ & $4,6 \pm 1,25^{\text {tn }}$ \\
\hline F1 & $5,3 \pm 1,32^{\text {tn }}$ & $4,5 \pm 1,19^{\text {tn }}$ & $3,8 \pm 1,39 b$ & $4,4 \pm 1,31^{\text {tn }}$ \\
\hline F2 & $5,6 \pm 1,31^{\mathrm{tn}}$ & $4,7 \pm 1,27^{\mathrm{tn}}$ & $4,4 \pm 1,45^{\mathrm{ab}}$ & $4,7 \pm 1,10^{\text {tn }}$ \\
\hline F3 & $5,8 \pm 1,21^{\text {tn }}$ & $4,9 \pm 1,45^{\text {tn }}$ & $5,0 \pm 1,39^{a}$ & $5,0 \pm 1,49^{\text {tn }}$ \\
\hline
\end{tabular}

Keterangan:

Huruf yang sama di belakang angka menunjukkan tidak berbeda nyata

*) F0: Kontrol, F1: CMC 1\% + Tween 80 2\%, F2: Gelatin 2\%, F3: Gelatin 1\% + Tween 80 0,5\%

**) (1) sangat tidak suka, (2) tidak suka, (3) agak tidak suka, (4) netral, (5) agak suka, (6) suka, (7) sangat suka

tn = tidak nyata 
Berdasarkan data yang diperoleh pada Tabel 3, menunjukkan bahwa skor rasa yang tertinggi terdapat pada formula (F3) dengan skor 5,0 yang berarti agak suka. Hal ini disebabkan karena gelatin dan tween 80 tidak memberikan efek rasa getir (susah ditelan), sehingga memberikan intensitas rasa yang agak disukai, sedangkan $\mathrm{F} 1$ (Tween 80 dan CMC) memiliki skor rasa lebih rendah dengan skor 3,8 yang agak tidak suka cenderung netral. Formula F1 memiliki skor yang paling rendah diduga karena memiliki kekentalan yang paling tinggi sehingga rasa yang diperoleh dari formula (F1) kurang disukai oleh panelis. Sarungallo et al. (2014) juga melaporkan bahwa tingkat penerimaan rasa dipengaruhi oleh viskositas emulsi minyak buah merah yang dihasilkan, dimana semakin rendah viskositas emulsi minyak buah merah maka akan memberikan intensitas rasa manis yang lebih tinggi dan lebih disukai.

Tingkat kesukaan panelis secara keseluruhan terhadap bubur daging buah merah (Tabel 3) menunjukkan bahwa keempat formula bubur daging buah merah berkisar antara netral sampai agak suka dengan skor 4,6 - 5,0. Hal ini menunjukkan bahwa keempat formula bubur daging buah merah dapat diterima oleh panelis.

\section{Kesimpulan}

Bubur daging buah merah dari keempat formula yang dihasilkan memiliki warna merah hingga merah oranye, beraroma khas buah merah, pH 6,6, viskositas 108 - 150 dPa.s, serta total padatan terlarut 8,4 - 8,5 ${ }^{\circ} \mathrm{Brix}$, dengan kestabilan emulsi 2 sampai 7 hari. Formula yang paling disukai berdasarkan karakteristik organoleptiknya adalah F3 dengan komposisi daging buah merah 95,1\%, Tween $800,5 \%$, gelatin 1\%, garam $0,3 \%$, gula $3 \%$ dan asam sitrat $0,1 \%$; memiliki tingkat penerimaan warna dengan skor 5,8 (agak suka sampai suka), aroma 4,9 (netral sampai agak suka), rasa 5,0 (agak suka), dan tampilan produk secara keseluruhan 5,0 (agak suka).

\section{Ucapan Terima Kasih}

Peneliti menyampaikan terima kasih kepada PT. Indofood atas dana yang diberikan melalui hibah penghargaan bagi peneliti unggul bidang pengembangan pangan, dalam program Riset Indofood Nugraha (IRN) 2017 - 2018 dengan nomor kontrak SKE.030/CC/IX/2017.

\section{Daftar Pustaka}

Badan Standarisasi Nasional (BSN). 2013. Standar Nasional Indonesia. SNI 7841:2013. Puree Buah. BSN, Jakarta.
Buckle, K. A., Edwards, R. A., Fleet, G. H., \& Wootton, M. (2013). Ilmu Pangan. Jakarta : Universitas Indonesia Press.

Cahyadi, W. (2012). Analisis dan aspek kesehatan bahan tambahan pangan. Bumi Aksara. Jakarta.

Effendi, S. (2015). Teknologi Pengolahan dan Pengawetan Pangan. Bandung : Penerbit Alfabeta.

Farikha, I. N, Anam, C., \& Widowati, E. (2013). Pengaruh Jenis Dan Konsentrasi Bahan Penstabil Alami Terhadap Karakteristik Fisikokimia Sari Buah Naga Merah (Hylocereus polyrhizus) Selama Penyimpanan. J Teknol Hasil Pertanian, 2(1):30-38.

Hasniati. (2012). Studi Pembuatan Permen Buah Dengen (Dillenia Serrata Thumb). Skripsi. Fakultas Pertanian, Universitas Hasanuddin. Makassar.

Hayati, I.N., Che Man, Y.B., Tan, C.P., \& Aini, I N. (2011). Effects of Xanthan Gum and Carboxymethyl Cellulose on Crytallization Behavior and Droplet Characteristics of Oil-inWater Emulsions. Empowering Science, Technology and Innovation Towards a Better Tomorrow: 318-323

Hsu, J.P., \& Nacu, A. (2003). Behavior of soybean oilin-water emulsion stabilized by nonionic surfactant. J Colloid Interf Sci, 259: 374-381.

Joshi, T., Mata J., \& Bahadur, P. (2012). Micellization and interaction of anionic and nonionic mixted surfactant system in water. Colloids and Surfaces A: Physicochemical Engeineering Aspects, 260(1-3): 209-215.

Kumalasari, R., Ekafitri, R., \& Desnilasari, D. (2015). Pengaruh Bahan Penstabil dan Perbandingan Bubur Buah Terhadap Mutu Sari Buah Campuran Pepaya-Nenas. J. Hort., 25 (3): 266276.

Murtiningrum \& Silamba, I. (2010). Pemanfaatan Pasta Buah Merah (Pandanus conoideus Lamk) sebagai bahan substitusi Tepung Ketan dalam Pembuatan Dodol. J. Agt, 4(1): 1-7.

Murtiningrum, Lisangan, M. M, \& Edoway, Y. (2012). Pengaruh Preparasi Ubi Jalar (Ipomoea Batatas) Sebagai Bahan Pengental Terhadap Komposisi Kimia dan Sifat Organoleptik Saus Buah Merah (Pandanus conoideus L). J. Agt, 6(1): 1-7.

Murtiningrum, Sarungallo, Z. L., Cepeda, G. N., \& Olong, N. (2013). Stabilitas Emulsi Minyak Buah Merah (Pandanus conoideus L) pada Berbagai Nilai Hydrophile-Lyphophile Balance (HLB) Pengemulsi. J. Teknol. Industri Pertanian, 23(1):30-37.

Nishigaki, T. M., \& Waspodo, I. S. (2007). Khasiat Buah Merah Sebuah Kajian di Jepang, Rahasia Senyawa Anti Kanker $\beta$-Cryptoxanthin. Jakarta : CV. Cindy Printing. 
Roreng, M.K., \& Nishigaki, T. (2013). Buah Merah and Papuan People. Warta IHP, 30(1): 37-48.

Sarungallo, Z. L., Murtiningrum, Santoso. B., Roreng, M. K., \& Latumahina, R. M. M. (2016). Nutrien content of three clones of red fruid (Pandanus conoideus) during the maturity development. Int. Food Res. J, 23(3):1217-1225.

Sarungallo, Z. L., Murtiningrum, Uhi, H.T., Roreng, M. K., \& Pongsibidang, A. (2014). Sifat Organoleptik, Sifat Fisik, serta Kadar $\beta$-karoten dan $\alpha$-tokoferol Emulsi Buah Merah (Pandanus conoideus). Agritech, 34(2):177-183.

Sarungallo, Z.L., Hariyadi, P., Andarwulan, N., \& Purnomo, E. H. (2019). Keragaman
Karakteristik Fisik Buah, Tanaman dan Rendemen Minyak dari 9 klon Buah Merah (Pandanus conoideus). J. Agribisnis Perikanan, 12 (1): 70-82.

Schreiber, R., \& Gareis, H. (2007). Gelatine handbook: Theory and industry practice. Willey-VCH. Weinhem.

Setyaningsih, D., Apriyantono, A., \& Sari, M.P. (2010). Analisis Sensori untuk Industri Pangan dan Agro. Bogor: Institut Pertanian Bogor Press.

Suryani, A. Sailah, I., \& Hambali, E. (2002). Teknologi Emulsi. Skripsi. Fakultas Teknologi Pertanian, Institut Pertanian Bogor. 